\author{
Leszek Czerwonka \\ University of Gdańsk \\ e-mail: leszek.czerwonka@ug.edu.pl \\ ORCID: 0000-0002-8438-6443
}

\title{
EFFICIENCY IN POLISH LISTED COMMERCIAL BANKS: A DEA APPROACH
}

EFEKTYWNOŚĆ POLSKICH GIELDOWYCH
BANKÓW KOMERCYJNYCH: PODEJŚCIE DEA

DOI: $10.15611 / \mathrm{pn} .2019 .5 .01$

JEL Classification: G21, D24, C61

\begin{abstract}
Summary: The subject of the research presented in this paper is the efficiency of key commercial banks in Poland. The research sample includes 12 banks listed on the Warsaw Stock Exchange, which hold over $80 \%$ of the assets of the entire commercial banks sector in Poland. The research period is 2013-2018. The aim of the research was to examine whether the largest commercial banks are more efficient than the others and to determine the main reasons for the inefficiency of commercial banks. Data Envelopment Analysis (DEA) was used as the research method. The obtained results indicate that the average efficiency is 0.903 . It turns out that the largest banks are on average quite efficient and do not have much room for improvement. In the case of large banks, the average technical efficiency PE is 0.96 , while in the case of pure technical efficiency PTE it is as high as 0.99 . This indicates that the largest Polish banks manage their resources very efficiently.
\end{abstract}

Keywords: banking, commercial banks, efficiency, Data Envelopment Analysis, DEA.

Streszczenie: Przedmiotem badania przedstawionego w niniejszym artykule jest efektywność kluczowych banków komercyjnych w Polsce. Próba badawcza obejmuje 12 banków notowanych na Giełdzie Papierów Wartościowych w Warszawie, które posiadają ponad $80 \%$ aktywów całego sektora banków komercyjnych w Polsce. Okres badania to lata 2013-2018. Celem badania było sprawdzenie, czy największe banki komercyjne są bardziej efektywne od pozostałych oraz wskazanie głównych przyczyn nieefektywności banków komercyjnych. Jako metodę badawczą zastosowano Data Envelopment Analysis (DEA). Uzyskane wyniki wskazują, że przeciętna efektywność wynosi 0,903. Okazało się także, że największe banki są przeciętnie dość efektywne i nie mają zbyt wielkich możliwości poprawy - przeciętna efektywność techniczna wynosi 0,96, w przypadku zaś „,czystej efektywności technicznej” PTE wynosi ona aż 0,99 . To wskazuje, że największe polskie banki zarządzają swoimi zasobami bardzo efektywnie.

Słowa kluczowe: bankowość, banki komercyjne, efektywność, Data Envelopment Analysis, DEA. 


\section{Introduction}

The subject of the research presented in this paper is the efficiency of key commercial banks in Poland. The financial sector, headed by the banking sector, is treated as the engine of economic growth. Banks operating in an efficient way increase consumer welfare (allowing for a more favourable distribution of consumption over time) and contribute to output and productivity growth in the economy as a whole. [Marcinkowska et al. 2014].

The Polish banking sector consists of two parts: the commercial banking sector and the cooperative banking sector. Between these two sectors, the main role is played by the commercial banking sector, which holds over $90 \%$ of the assets of the entire banking sector [NBP 2018, p. 85]. In this study, the commercial banking sector was analysed, and the research sample includes entities holding over $80 \%$ of the assets of the commercial banking sector (Table 1). The entities analysed in this study have therefore three-quarters of the assets of the entire banking sector in Poland.

The aim of the research is to examine whether the largest commercial banks are more efficient than the other commercial banks. The research hypothesis states that the largest commercial banks are more efficient than the remaining banks in the research sample. An additional objective is to identify the main reasons for the inefficiency of commercial banks. This study contributes to the current knowledge on the existence of the size effect in the banking efficiency in Poland, and whether the reasons for the inefficiency may include the poor management of resources or operating on an inadequate scale. Additionally, thanks to the separation of the group of efficient banks, further research is possible, which, through the detailed analysis of this group will make it possible to find more specific determinants of this efficiency.

The 2013-2018 period was adopted for the analysis, while the commercial banks listed on the Warsaw Stock Exchange were taken into account as the subject of the study. The sample is homogeneous because only universal banks were considered, which is important in this type of research. The research was based on the Data Envelopment Analysis (DEA) method, which allows to identify units lying on the efficiency frontier and units using their resources in an inefficient way. However, in order to carry out such an analysis properly, the mechanism of processing resources (inputs) into outputs should be the same in the analysed entities.

The paper is structured as follows. The next section details measuring bank efficiency using the DEA method. Section 3 provides a brief review of the relevant literature. Section 4 presents the methodology and data. The empirical results are presented in Section 5. The final section provides a conclusion of the main findings.

\section{Theoretical background - measuring bank efficiency}

The examination of the efficiency of enterprises is based on the definition of measurement proposed by Farrell [1957]. Using this definition, the method based on 
a non-parametric linear programming approach was introduced by Charnes, Cooper and Rhodes [1978]. This method is called Data Envelopment Analysis (DEA). This technique allows to determine the relative efficiency of a homogeneous set of decision-making units in their use of multiple inputs to produce multiple outputs. DEA measures the efficiency of a decision-making unit (DMU) relative to other similar DMUs, assuming that all DMUs lie on or below the efficiency frontier. The value of the efficiency measure is between 0 and 1 , where 1 is obtained by the efficient units lying on the efficiency frontier. DEA can also identify, for inefficient DMUs, the sources and level of inefficiency for each of the inputs and outputs [Řepková 2014].

The basic models within a DEA method include the models developed by Charnes, Cooper and Rhodes [1978] (hence the model is called CCR) and by Banker, Charnes and Cooper [1984] (the BCC model). The CCR model assumes the existence of constant returns to scale (CRS) and results in overall technical efficiency. The BCC model is based on the assumption that DMUs are characterised by variable returns to scale (VRS). The VRS assumption allows to obtain pure technical efficiency, which is a measure of technical efficiency without scale effects. By using these two models it is possible to obtain three efficiency measures: technical efficiency TE (from the CCR model), pure technical efficiency PTE (from the BCC model) and scale efficiency SE (from dividing TE by PTE) [Řepková 2014].

DEA models can be input or output oriented. Input orientation aims to minimize inputs while satisfying at least the given output levels. Output orientation attempts to maximize outputs without increasing inputs. Input orientation is preferred in banking analyses because banks usually have no direct control over the amount of services demanded by their clients, however they can control inputs [Yilmaz, Güneş 2015].

Another important issue is the choice of inputs and outputs. In studies on bank efficiency there exist mainly two approaches, namely production and intermediation, determining the inputs and outputs [Sealey Jr, Lindley 1977]. In the production approach (initiated by Benston [1965]), banks are considered as service providers for customers. The inputs involve physical variables such as labour, capital and materials. The outputs are generally related to the services available to customers, which may include deposits and loans. In the intermediation approach (initiated by Sealey Jr and Lindley [1977]), the main function of banks (as intermediaries) is to collect funds (deposits are inputs) and convert them into loans and other profitable assets (outputs) using physical capital and labour (inputs) [Henriques et al. 2018].

The approaches outlined above are among the basic and most commonly used. However, modifications and extensions are also used. For example, the measurement of such efficiencies can be found as technical efficiency, allocative efficiency and cost efficiency [Eyceyurt Batir, Volkman, Gungor 2017]. Two-stage analyses are also used. In the case of bank studies using the DEA method, the expression "two-stage" may have several meanings. The first type of a two-stage analysis involves dividing the production process of a bank into two stages: for example, 
the productivity stage and the profitability stage [Zha et al. 2016] or e.g., production process and intermediation process [Holod, Lewis 2011; Wang et al. 2014]. Another type of a two-stage analysis can be to calculate the efficiency in the first stage and to search for the efficiency determinants in the second stage using a panel model or the Tobit model [Eyceyurt Batir, Volkman, Gungor 2017; Kamarudin et al. 2019]. Among the approaches used, a procedure based on a bootstrap can also be found, which is a computer-based method of resampling from the original data in order to assign statistical properties for the quantities of interest [Assaf, Barros, Matousek 2011].

DEA has some limitations. In cases where a sample is analysed and not the entire population, DMUs indicated as efficient are actually efficient only in relation to other units in the sample. It may be that non-sample units are more efficient than those considered to be efficient in the sample.

One of the advantages of the DEA method, in turn, is the ability to understand the nature of inefficiency of units. DEA can be used to identify areas where an entity is less efficient than other entities. In this way, it is possible to implement measures to improve the efficiency of a given unit. Therefore, it is worthwhile to compare the profitability analysis with the DEA results and seek an explanation in the case of significant differences.

\section{Review of empirical studies - banking efficiency}

The DEA method is quite often used around the world to assess the efficiency of banks. There are a few examples below that may indicate the directions of the research, the detailed methods used and the results for particular countries.

Staub, Da Silva e Souza and Tabak [2010] analysed the situation of 184 Brazilian banks between 2000 and 2007, based on the intermediation approach. The results indicate that there are no differences in economic efficiency in terms of type of activity or size of bank, while state-owned banks are more cost efficient than private, domestic or foreign banks [Staub, Da Silva e Souza, Tabak 2010].

For Brazil, a study was also conducted by Henriques et al. [2018]. The research period was 2012-2016, while the research sample consisted of 37 banks. The aim was to examine which banks are most efficient, especially depending on their size, and to identify the main reasons for inefficiency. The conclusions obtained indicate that the inefficiency of banks is slightly more related to technical and administrative issues and to a lesser extent to the scale of operations. However, the size of the bank is important. The inefficiencies of larger banks are due to excessive scale, while the inefficiencies of small banks are due to the insufficient scale of operations [Henriques et al. 2018].

Assaf, Barros, Matousek [2011] examined nine Saudi banks over the period 1999-2007, resulting in 81 observations. They used the intermediation approach and the bootstrapped two-stage DEA as the measurement method. In the first stage the DEA-VRS (variable returns to scale) bootstrapped model was used to calculate the 
efficiency. In the second stage, the bootstrapped truncated regression model was used to identify the covariates that explain technical efficiency. The results showed that banks with foreign capital should improve technical efficiency. The opposite results were expected, because the assertion that foreign capital brings managerial skills is widespread [Assaf, Barros, Matousek 2011].

Holod and Lewis [2011] solved the problem of whether to use the intermediation or the production approach and combined them. In this way they got rid of the dilemma of whether deposits are an input (intermediation approach) or an output (production approach) and made deposits an intermediate product.

Wang et al. [2014] based on the example of 16 Chinese banks for the years 2003-2011, compared the production approach, the intermediation approach and the additive two-stage model. The two-stage model assumes that the bank's activity covers both the production process and the intermediation process, and both of these processes should be taken into account during the analysis. The results of their research indicate that the two-stage model is more effective than the standard black box DEA approach. Such a method made it possible to conclude that the inefficiency initially resulted from the deposit-producing sub-process. Then, however, the efficiency of the Chinese banking system improved considerably, first by improving the deposit-producing process and then the profit-earning process. The decrease in the value of non-performing loans was important for this process [Wang et al. 2014].

Under Chinese conditions, the analysis was also prepared by Zha et al. [2016], who analysed 25 major banks for 2008-2012. They used a dynamic two-stage slacksbased measure model, where the first stage is the productivity stage and the second stage is the profitability stage. The conclusions of the study indicate that Chinese banks in this period show both technical and scale inefficiency, resulting from inefficiencies in productivity and profitability stages [Zha et al. 2016].

Eyceyurt Batir, Volkman and Gungor [2017] conducted a study for 27 conventional banks and four participation (Islamic) banks in Turkey in the period 2005-2013. The study was based on the intermediation approach and aimed at finding technical efficiency (TE), allocative efficiency (AE) and cost efficiency (CE) for both groups of banks. In the second stage the Tobit regression analysis was used to determine the factors influencing the efficiency. The results of DEA indicate that the average conventional bank efficiency was lower than the average participation bank efficiency in each year [Eyceyurt Batir, Volkman, Gungor 2017].

Kamarudin et al. [2019] analysed 17 Malaysian Islamic banks in the period 2006-2015. They applied the DEA method in the first stage to examine revenue efficiency. In the second stage they used panel regression models to find the determinants of the revenue efficiency. They found that the determinants of efficiency in the Malaysian domestic Islamic banks are the bank's market power, liquidity, and management quality. At the same time, it turned out that the Malaysian domestic Islamic banks are less efficient than the foreign Islamic banks [Kamarudin et al. 2019]. 
For Poland the research was carried out by Pawłowska [2004], who conducted a study for the period 1997-2002, which aimed to establish links between the efficiency, level of competition and financial stability of the Polish banking sector. The study showed that most of the analysed Polish banks operated in the area of increasing returns to scale. This result could indicate that there were still reasons for further mergers, which should contribute to the improvement of technical efficiency in the banking sector [Pawłowska 2004].

Domagała [2007] applied the CCR model and 24 banks were analysed in the years 2001-2004. In the study, however, less emphasis was placed on the efficiency of banks, but rather on the analysis of the method. As the conclusions from the analysis, the author pointed out that it is advantageous to conduct the DEA analysis in the form of a panel approach (spatial and temporal analysis), because it makes it possible to examine the efficiency in a given year against the background of the results of operations in other years. This allows to verify the results and to catch the very unstable ones, which are questionable [Domagała 2007].

Svitalkova's study [2014] covered the Czech Republic and Poland in the period 2004-2011, as well as Slovakia, Slovenia, Austria and Hungary. From each country, 8-12 of the largest banks were analysed. The aim of the study was to compare the banking systems of several EU countries and to reveal the most important sources of inefficiency. The study's findings showed that the most efficient banking systems are Austrian and Czech, while the least efficient are Slovenian and Slovak. The source of inefficiencies in all countries was too small lending (providing too few loans) and at the same time the large value of loan loss provisions [Svitalkova 2014].

The efficiency of the Czech banks was also studied by Řepková [2014]. She used the DEA window analysis to evaluate 11 Czech commercial banks in 2003-2012. The average efficiency in the constant returns to scale model was $70 \%$ to $78 \%$, whereas in the variable returns to scale model it was $84 \%$ to $89 \%$. It turned out that the group of large banks was less efficient than the other banks [Řepková 2014].

\section{Research material and methodology}

The analysis for this study was carried out using two models, CCR and BCC, in order to obtain technical efficiency, pure technical efficiency and scale efficiency from dividing the two previous values. As in the other studies discussed above, in this study an input orientation was adopted, where outputs are maintained as constant and inputs are reduced to seek efficiency. Generally, it is easier for banks to reduce their number of employees rather than to increase its total loans, as this would depend on third parties' decision-making. The intermediation approach was adopted as the model describing the bank's function, hence the same variables were used as those used by [Henriques et al. 2018], inputs: fixed assets (x1), personnel expenses (x2), total deposits (x3) and for outputs: total loans (y1). The data was obtained from Thomson Reuters, under the special Partnership Project between 
Thomson Reuters and the University of Gdańsk. The variables $\mathrm{x} 2$, $\mathrm{x} 3$ and $\mathrm{y} 1$ were taken directly from the financial statements, while as the $\mathrm{x} 1$ variable, the sum of the following items was taken: Property/Plant/Equipment, Net and Intangibles, Net. The analysis period covers the years 2013-2018. The examined entities are all the Polish listed banks: Alior Bank (ALB), Bank Handlowy w Warszawie (BHW), Bank Millennium (MIL), Bank Ochrony Srodowiska (BOS), Bank Polska Kasa Opieki (PEO), BNP Paribas Bank Polska (BNP), Getin Noble Bank (GNB), Idea Bank (IDA), ING Bank Śląski (ING), MBANK (MBK), Powszechna Kasa Oszczędności Bank Polski (PKO), and Santander Bank Polska (SPL). Getin Holding, which also belongs to the commercial banking sector on the Warsaw Stock Exchange and whose data was available in the Thomson Reuters system, was excluded from the sample. The exclusion was made in order to maintain the homogeneity of the sample. Getin Holding is not a single bank but an entity holding shares of many banks. Hence its inclusion in the sample could distort the results and conclusions regarding the efficiency of the banking entities. Such a sample selection was caused by the availability of data on Thomson Reuters. It should be noted, however, that this sample covers $83 \%$ of the commercial banks sector in 2018 , counted as a share in total assets of the sector (Table 1).

Table 1. Total Assets of the Polish commercial banking sector and the analysed banks (PLN billions)

\begin{tabular}{|c|c|r|r|r|r|r|r|}
\hline \multirow{3}{*}{ Number } & Year & 2013 & 2014 & 2015 & 2016 & 2017 & 2018 \\
\cline { 2 - 8 } & Sample share in sector (\%) & $71 \%$ & $76 \%$ & $78 \%$ & $79 \%$ & $78 \%$ & $83 \%$ \\
\cline { 2 - 8 } & Sector Total Assets & 1277.2 & 1394.4 & 1458.3 & 1549.5 & 1602 & 1691.7 \\
\cline { 2 - 8 } & Total Assets for the sample & 908.0 & 1053.5 & 1139.1 & 1216.9 & 1245.2 & 1409.4 \\
\hline 1 & ALR & 25.6 & 30.2 & 40.0 & 61.2 & 69.5 & 73.4 \\
\hline 2 & BHW & 45.4 & 49.8 & 49.5 & 45.2 & 43.0 & 49.3 \\
\hline 3 & BNP & 35.8 & 40.5 & 65.4 & 72.3 & 72.7 & 109.0 \\
\hline 4 & BOS & 18.4 & 19.7 & 20.9 & 20.8 & 19.7 & 18.3 \\
\hline 5 & GNB & 63.6 & 68.8 & 70.4 & 66.2 & 59.8 & 49.9 \\
\hline 6 & IDA & 7.4 & 15.1 & 18.8 & 21.3 & 23.7 & 20.5 \\
\hline 7 & ING & 104.3 & 118.0 & 123.5 & 133.7 & 124.6 & 145.8 \\
\hline 8 & MBK & 57.0 & 60.7 & 66.2 & 68.8 & 71.1 & 80.5 \\
\hline 9 & MIL & 158.5 & 167.6 & 168.8 & 174.2 & 185.5 & 191.1 \\
\hline 10 & PEO & 199.2 & 248.7 & 266.9 & 285.6 & 296.9 & 324.3 \\
\hline 11 & PKO & 106.1 & 134.5 & 139.7 & 150.1 & 152.7 & 205.9 \\
\hline 12 & SPL & & & & & \\
\hline
\end{tabular}

Source: own work based on [KNF 2015; KNF 2016; KNF 2019; Thomson Reuters 2019]. 
Table 1 shows the assets of the banks covered by the study in relation to the total assets of the sector. Such a significant share of the research sample in the total of the sector shows that the results obtained can be treated as significant from the point of view of the sector as a whole.

\section{Results}

Table 2. Technical, Pure Technical and Scale Efficiency of the examined DMUs

\begin{tabular}{|c|c|c|c|}
\hline \multirow{2}{*}{ DMUs } & \multicolumn{3}{|c|}{$2013-2018$ Average } \\
\cline { 2 - 4 } & TE & PTE & SE \\
\hline 1 & 0.957 & 0.970 & 0.986 \\
\hline 2 & 0.561 & 0.597 & 0.941 \\
\hline 3 & 0.937 & 0.949 & 0.987 \\
\hline 4 & 0.941 & 1.000 & 0.941 \\
\hline 5 & 0.954 & 0.961 & 0.993 \\
\hline 6 & 0.683 & 0.932 & 0.719 \\
\hline 7 & 0.915 & 0.953 & 0.961 \\
\hline 8 & 1.000 & 1.000 & 1.000 \\
\hline 9 & 1.000 & 1.000 & 1.000 \\
\hline 10 & 0.913 & 0.983 & 0.929 \\
\hline 11 & 0.993 & 1.000 & 0.993 \\
\hline 12 & 0.978 & 0.996 & 0.982 \\
\hline Minimum & 0.561 & 0.597 & 0.719 \\
\hline Maximum & 1.000 & 1.000 & 1.000 \\
\hline Average & 0.903 & 0.945 & 0.953 \\
\hline
\end{tabular}

Source: own work.

for $9.7 \%$ of the technical inefficiency banks could produce the same amount of services with $9.7 \%$ less inputs.

The results of the entire research sample were divided into two parts: five banks (PKO, PEO, SPL, MBK, ING), which in each of the analysed years were significantly larger in terms of the value of assets (Table 1) and the remaining seven banks. Five banks were called large banks in the study, the others were called medium banks because it should be noted that these are still big banks, listed on the stock exchange, having nationwide branch networks and they are larger than the group of banks not included in the study (e.g. unlisted banks or cooperative banks).

Table 3 shows that the average technical efficiency for large banks was 0.96 during the period considered, while for medium-sized banks it was 0.86. The difference between these mean values is statistically significant. H0 with equal 
Table 3. Mean test

\begin{tabular}{|c|c|c|c|c|c|c|c|}
\hline & Mean - Medium banks & St. dev. & $\mathrm{N}$ & Mean - Large banks & St. dev. & $\mathrm{N}$ & p-value \\
\hline TE & 0.86 & 0.18 & 42 & 0.96 & 0.06 & 30 & $0.003 * * *$ \\
\hline PTE & 0.92 & 0.14 & 42 & 0.99 & 0.04 & 30 & $0.005 * * *$ \\
\hline SE & 0.94 & 0.11 & 42 & 0.97 & 0.04 & 30 & $0.056^{*}$ \\
\hline
\end{tabular}

* statistical significance at the level of $0.1 ; * *$ statistical significance at the level of 0.05 ; *** statistical significance at the level of 0.01

Source: own work.

mean values was rejected and at the significance level of 0.01 (p-value 0.003) H1 was accepted that the average technical efficiency of large banks is higher than the average technical efficiency of medium-sized banks. The same results were obtained for PTE and SE. In the case of each of these efficiencies, higher efficiency is achieved on average by banks from the group of larger banks. For PTE, the average efficiency of medium banks is 0.92 , while for larger banks it is 0.99 . For SE, the average efficiency of medium banks is 0.94 , while for larger banks it is 0.97 . In both cases, these differences are statistically significant.

\section{Conclusions}

The study's limitations include the composition of the sample, which includes only 12 banks. However, many other similar studies are based on a sample of a similar size. In this case it should be noted that the analysed banks have $83.3 \%$ of the assets of the entire commercial banking sector in Poland. The results based on the analysis of entities holding five-sixths of the assets of the sector should be carefully considered. The obtained results indicate that in the group of the Polish banks listed on the stock exchange, these banks on average could produce the same amount of services with $9.7 \%$ less inputs. Such a result is made up, to approximately the same extent (about $5 \%$ each), of pure technical inefficiency (related to the inappropriate management of resources) as well as scale inefficiency (caused by the incorrect scale of banking operations).

It can be seen, however, that after dividing this group into particularly large banks and others, it turns out that large banks are on average quite efficient and do not have much room for improvement. In the case of larger banks, the average technical efficiency TE is 0.96 , while in the case of PTE it is as high as 0.99 (on average for all larger banks, for the whole period under review). This indicates that the largest Polish banks manage their resources very efficiently. The results differ from many results obtained by other authors. Henriques et al. [2018] analysed the Brazilian banks and found that the largest banks were among the less efficient. On the other hand, Staub, Da Silva E Souza and Tabak [2010] also examining the situation 
of Brazilian banks, obtained the result that the size of the bank does not affect their efficiency. Similarly, Kumar and Gulati [2009], for the sample of Indian banks, found out that there is no statistically significant difference between the efficiency of large and smaller banks. In contrast, Seiford and Zhu [1999], analysing the efficiency of the US banks, found that larger banks are more efficient. On the basis of these few examples, no conclusions can be drawn. However, they show that one of the possible ways of research is to check whether the greater efficiency of large banks can be found in more developed countries. This will be the subject of further analysis by the author.

\section{Bibliography}

Assaf A.G., Barros C.P., Matousek R., 2011, Technical efficiency in Saudi banks, Expert Systems with Applications, vol. 38, pp. 5781-5786.

Banker R.D., Charnes A., Cooper W.W., 1984, Some models for estimating technical and scale inefficiencies in data envelopment, Management Science, vol. 30, no. 9, pp. 1078-1092.

Benston G.J., 1965, Branch banking and economies of scale, The Journal of Finance, vol. 20, no. 2, pp. 312-331.

Charnes A., Cooper W.W., Rhodes E., 1978, Measuring the efficiency of decision-making units, European Journal of Operational Research, vol. 2, no. 6, pp. 429-444.

Domagała A., 2007, Przestrzenno-czasowa analiza efektywności jednostek decyzyjnych metoda Data Envelopment Analysis na przykładzie banków polskich, Badania Operacyjne i Decyzje, vol. 3-4, pp. 35-56.

Eyceyurt Batir T., Volkman D.A., Gungor B., 2017, Determinants of bank efficiency in Turkey: participation banks versus conventional banks, Borsa Istanbul Review, vol. 17, no. 2, pp. 86-96.

Farrell M.J., 1957, The measurement of productive efficiency, Journal of the Royal Statistical Society, Series A (General), vol. 120, no. 3, pp. 253,281.

Henriques I.C., Amorim Sobreiro V., Kimura H., Barberio Mariano E., 2018, Efficiency in the Brazilian banking system using data envelopment analysis, Future Business Journal, vol. 4, pp. 157-178.

Holod D., Lewis H.F., 2011, Resolving the deposit dilemma: a new DEA bank efficiency model, Journal of Banking \& Finance, vol. 35, pp. 2801-2810.

Kamarudin F., Sufian F., Nassir A.M., Anwar N.A.M., Hussain H.I., 2019, Bank efficiency in Malaysia: a DEA approach, Journal of Central Banking Theory and Practice, vol. 8, no. 1, pp. 133-162.

KNF, 2015, Raport o sytuacji banków 2014, https://www.knf.gov.pl/knf/pl/komponenty/img/RAPORT O_SYTUACJI_BANKOW_2014_12_41472.pdf (10.07.2019).

KNF, 2016, Raport o sytuacji banków 2015, https://bip.knf.gov.pl/pliki/RAPORT_O_SYTUACJI_ BANKOW_2015_60314_tcm6-60314.pdf(10.07.2019).

KNF, 2019, Raport o sytuacji banków 2018, https://www.knf.gov.pl/knf/pl/komponenty/img/RAPORT _O_SYTUACJI_BANKOW_2018_65694.pdf(10.07.2019).

Kumar S., Gulati R., 2009, Measuring the efficiency, effectiveness and performance of Indian public sector banks, International Journal of Productivity and Performance Management, vol. 59, no. 1, pp. 51-74.

Marcinkowska M., Wdowiński P., Flejterski S., Bukowski S., Zygierewicz M., 2014, Wpływ regulacji sektora bankowego na wzrost gospodarczy - wnioski dla Polski, Materiały i Studia, vol. 305.

NBP, 2018, Rozwój systemu finansowego w Polsce w 2017 r., https://www.nbp.pl/systemfinansowy/ rozwoj2017.pdf (10.07.2019). 
Pawłowska M., 2004, Efektywność, konkurencyjność i koncentracja na polskim rynku bankowym w latach 1997-2002 - związi między pojęciami, Bank i Kredyt, vol. 6, pp. 59-66.

Řepková I., 2014, Efficiency of the Czech banking sector employing the DEA window analysis approach, Procedia Economics and Finance, vol. 12, pp. 587-596.

Sealey Jr C.W., Lindley J.T., 1977, Inputs, Outputs, and a theory of production and cost at depository financial institutions, The Journal of Finance, vol. 32, no. 4, pp. 1251-1266.

Seiford L.M., Zhu J., 1999, Profitability and marketability of the Top 55 U.S. commercial banks, Management Science, vol. 45, no. 9, pp. 1270-1288.

Staub R.B., Da Silva e Souza G., Tabak B.M., 2010, Evolution of bank efficiency in Brazil: A DEA approach, European Journal of Operational Research, vol. 202, pp. 204-213.

Svitalkova Z., 2014, Comparison and evaluation of bank efficiency in selected countries in the EU, Procedia Economics and Finance, vol. 12, pp. 644-653.

Thomson Reuters, 2019, Thomson Reuters database, Partnership Project between Thomson Reuters and the University of Gdańsk (24.06.2019).

Wang K., Huang W., Wu J., Liu Y.N., 2014, Efficiency measures of the Chinese commercial banking system using an additive two-stage DEA, Omega, vol. 44, pp. 5-20.

Yilmaz A., Güneş N., 2015, Efficiency comparison of participation and conventional banking sectors in Turkey between 2007-2013, Procedia - Social and Behavioral Sciences, vol. 195, pp. 383-392.

Zha Y., Liang N., Wu M., Bian Y., 2016, Efficiency evaluation of banks in China: a dynamic two-stage slacks-based measure approach, Omega, vol. 60, pp. 60-72. 


\section{Appendix}

Table 4. Summary statistics of Polish banks' efficiency (2013-2015)

\begin{tabular}{|c|c|c|c|c|c|c|c|c|c|}
\hline \multirow{2}{*}{ DMUs } & \multicolumn{3}{|c|}{2013} & \multicolumn{3}{|c|}{2014} & \multicolumn{3}{|c|}{2015} \\
\cline { 2 - 10 } & TE & PTE & SE & TE & PTE & SE & TE & PTE & SE \\
\hline 1 & 0.995 & 1.000 & 0.995 & 0.992 & 1.000 & 0.992 & 0.968 & 0.982 & 0.986 \\
\hline 2 & 0.530 & 0.548 & 0.967 & 0.514 & 0.563 & 0.913 & 0.519 & 0.537 & 0.966 \\
\hline 3 & 0.932 & 0.944 & 0.987 & 0.888 & 0.911 & 0.975 & 1.000 & 1.000 & 1.000 \\
\hline 4 & 0.951 & 1.000 & 0.951 & 0.913 & 1.000 & 0.913 & 1.000 & 1.000 & 1.000 \\
\hline 5 & 0.982 & 0.982 & 1.000 & 0.920 & 0.920 & 0.999 & 0.925 & 0.928 & 0.996 \\
\hline 6 & 0.766 & 1.000 & 0.766 & 0.744 & 1.000 & 0.744 & 0.855 & 1.000 & 0.855 \\
\hline 7 & 0.805 & 0.813 & 0.990 & 0.817 & 0.903 & 0.905 & 0.904 & 1.000 & 0.904 \\
\hline 8 & 1.000 & 1.000 & 1.000 & 1.000 & 1.000 & 1.000 & 1.000 & 1.000 & 1.000 \\
\hline 9 & 1.000 & 1.000 & 1.000 & 1.000 & 1.000 & 1.000 & 1.000 & 1.000 & 1.000 \\
\hline 10 & 0.876 & 1.000 & 0.876 & 0.876 & 1.000 & 0.876 & 0.956 & 1.000 & 0.956 \\
\hline 11 & 1.000 & 1.000 & 1.000 & 1.000 & 1.000 & 1.000 & 1.000 & 1.000 & 1.000 \\
\hline 12 & 0.923 & 0.974 & 0.948 & 0.944 & 1.000 & 0.944 & 1.000 & 1.000 & 1.000 \\
\hline Minimum & 0.530 & 0.548 & 0.766 & 0.514 & 0.563 & 0.744 & 0.519 & 0.537 & 0.855 \\
\hline Maximum & 1.000 & 1.000 & 1.000 & 1.000 & 1.000 & 1.000 & 1.000 & 1.000 & 1.000 \\
\hline Average & 0.942 & 0.938 & 0.957 & 0.884 & 0.941 & 0.938 & 0.927 & 0.954 & 0.972 \\
\hline
\end{tabular}

Source: own work.

Table 5. Summary statistics of Polish banks' efficiency (2016-2018)

\begin{tabular}{|c|c|c|c|c|c|c|c|c|c|}
\hline \multirow{2}{*}{ DMUs } & \multicolumn{3}{|c|}{2016} & \multicolumn{3}{c|}{2017} & \multicolumn{3}{|c|}{2018} \\
\cline { 2 - 10 } & TE & PTE & SE & TE & PTE & SE & TE & PTE & SE \\
\hline 1 & 0.949 & 0.970 & 0.978 & 0.931 & 0.955 & 0.975 & 0.908 & 0.915 & 0.993 \\
\hline 2 & 0.584 & 0.623 & 0.938 & 0.624 & 0.684 & 0.913 & 0.592 & 0.625 & 0.948 \\
\hline 3 & 0.979 & 0.992 & 0.987 & 0.932 & 0.953 & 0.978 & 0.891 & 0.893 & 0.998 \\
\hline 4 & 0.963 & 1.000 & 0.963 & 0.929 & 1.000 & 0.929 & 0.889 & 1.000 & 0.889 \\
\hline 5 & 0.961 & 0.974 & 0.987 & 0.939 & 0.963 & 0.975 & 1.000 & 1.000 & 1.000 \\
\hline 6 & 0.913 & 1.000 & 0.913 & 0.466 & 0.774 & 0.601 & 0.352 & 0.817 & 0.431 \\
\hline 7 & 0.964 & 1.000 & 0.964 & 1.000 & 1.000 & 1.000 & 1.000 & 1.000 & 1.000 \\
\hline 8 & 1.000 & 1.000 & 1.000 & 1.000 & 1.000 & 1.000 & 1.000 & 1.000 & 1.000 \\
\hline 9 & 1.000 & 1.000 & 1.000 & 1.000 & 1.000 & 1.000 & 1.000 & 1.000 & 1.000 \\
\hline 10 & 0.956 & 1.000 & 0.956 & 0.939 & 1.000 & 0.939 & 0.873 & 0.897 & 0.974 \\
\hline 11 & 1.000 & 1.000 & 1.000 & 1.000 & 1.000 & 1.000 & 0.958 & 1.000 & 0.958 \\
\hline 12 & 1.000 & 1.000 & 1.000 & 1.000 & 1.000 & 1.000 & 0.998 & 1.000 & 0.998 \\
\hline Minimum & 0.584 & 0.623 & 0.913 & 0.466 & 0.684 & 0.601 & 0.352 & 0.625 & 0.431 \\
\hline Maximum & 1.000 & 1.000 & 1.000 & 1.000 & 1.000 & 1.000 & 1.000 & 1.000 & 1.000 \\
\hline Average & 0.939 & 0.963 & 0.974 & 0.897 & 0.944 & 0.943 & 0.872 & 0.929 & 0.932 \\
\hline
\end{tabular}

Source: own work. 